\title{
How Fair are Group Assignments? A Survey of Students and Faculty and a Modest Proposal
}

\author{
Marilyn Ford \\ Griffith University, \\ Nathan, Australia
}

M.Ford@griffith.edu.au

\author{
Jenny Morice \\ University of Portsmouth, \\ Portsmouth, England
}

\section{Executive Summary}

Group assignments are becoming increasingly popular in education. While some academics would admit that they lessen their workload, many would say group assignments give students the "real world" group experience needed for later employment. Problems with group assignments have been noted in the literature, but the extent to which staff are aware of problems is not clear, nor is it clear whether students think group assignments could be valuable. The present study set out to obtain staff and student views on the problems with, and the worth of, group assignments and, given the comments, to consider a better strategy for implementing group work.

A questionnaire was administered to 69 students and 12 academicians in an IT school at a university. It was found that while nearly half the students reported frequently having problems with group assignments, only 2 of the 12 staff members reported frequently encountering problems. Reasons for the discrepancy are considered. The perceived benefits and negative aspects of group assignments were also considered. The students seem to put more store on sharing ideas and social interaction than staff and they are concerned about timetabling and logistical problems, which staff are unaware of. Students and staff are both concerned about the inequality of contribution by the different group members. Students do see potential value in group work; even for those who had frequently encountered problems, only just over half said they preferred individual assignments. It was found that many students believe they should have group assignments because they will be working in groups in the IT and Multimedia industries.

Given that students see the potential value of group assignments, but often encounter problems, this paper offers a new strategy that aims to maintain the good features of group assignments while removing the negative. We suggest that many problems with group assignments can be overcome by making group assignments more closely replicate conditions in industry. We propose a three-phase strategy using management techniques on a small scale: (1) the initiation phase where an academic staff me mber, who acts as a "group manager," advertises positions on projects, students apply for the positions, and appointments are made; (2) the management phase where the "group manager" and each group meet ac-

Material published as part of this journal, either on-line or in print, is copyrighted by the publisher of the Journal of Information Technology Education. Permission to make digital or paper copy of part or all of these works for personal or classroom use is granted without fee provided that the copies are not made or distributed for profit or commercial advantage AND that copies 1) bear this notice in full and 2) give the full citation on the first page. It is permissible to abstract these works so long as credit is given. To copy in all other cases or to republish or to post on a server or to redistribute to lists requires specific permission and payment of a fee. Contact Editor@ JITE.org to request redistribution permission. cording to an agreed schedule and where group members work according to contracts; and (3) the completion phase where a "post-mortem" and individual marking (not group marking) take place.

Keywords: group assignments, inequities in marking, industry-like group experience

The original version of this paper was published as one of the 24 "best" papers in the proceedings of the 2003 Informing Science and IT Education Conference in Pori, Finland http://2003.insite.nu 


\section{Introduction}

With less money to fund higher education and with increased student numbers, many academics are turning to group assignments to lessen their workload (Morris \& Hayes, 1997; Thong, 1995). Many argue that group assignments have educational benefits (Baskin, 2001; Candy, Crebert, \& O'Leary, 1994) and they may well have. However, some studies indicate that there are problems with group assignments (Michalchik, et al., 2001; Morris \& Hayes, 1997; Parsons \& Drew, 1996).

The benefits of group assignments are said to include: higher order thinking (Cohen, 1994); better communication and conflict management (Johnson \& Johnson, 1996); greater understanding (Fall, Webb, \& Chudowski, 2000); and the development of skills transferable to the work environment such as teamwork, time ma nagement, and interpersonal skills (Candy, et al., 1994). Problems identified with group assignments include: "freeriders" leaving all or most of the work to others (Brokaw \& Rudd, 2002; Morris \& Hayes, 1997); clashes between group members (Brokaw \& Rudd, 2002; Chang, 1999; Morris \& Hayes, 1997); and time management and organisational problems (Morris \& Hayes, 1997).

While studies have identified problems, it is not clear to what extent staff who give group assignments are aware of the problems. Due to increased workloads it could be that staff are, in fact, not well informed about problems. Further, while problems have been identified in the literature, it is not clear to what extent students, in particular Information Technology students, believe that group assignments could be valuable. If, indeed, it is found that students believe there could be value in group work despite problems they have experienced, then new strategies for group assignments need to be developed which take into account the experiences of staff and students.

\section{Background}

The present study investigated staff and student perceptions to group assignments in a Computing and Information Technology School.

Even though no formal School policy particularly encourages the use of group assignments, it is a commonly adopted assessment strategy within the School. However, there are often significant differences between subjects in the amount of group versus individual assignments used; for example, in a final year project subject, group assignments account for $100 \%$ of the assessable items, while a one semester web development subject was generally assessed as $60 \%$ group work and $40 \%$ individual assignments.

In addition, due to the popularity within the School of the use of group assignments it is often the case that a student will be involved in between one and four groups (each comprising between two and six members) per semester depending on the amount of credit points being studied by each individual. For

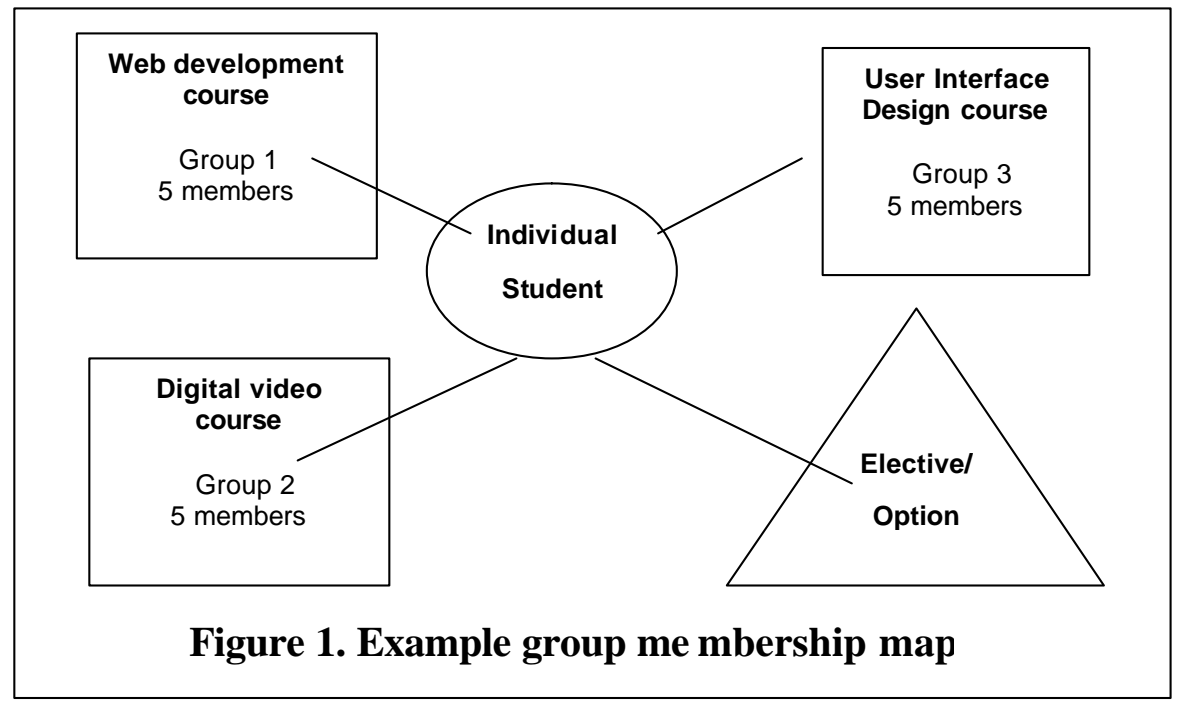


Ford \& Morice

example, a student studying multimedia and undertaking all designated core subjects in one semester at second year level would be in a group for each of the following semester long subjects: web development; digital video; and user interface design. The elective/option choice may or may not involve a group assignment. Such a situation is illustrated in Figure 1.

While some groups will contain common members, timetabling and logistical problems often preclude the formation of common groups across subjects. This means that full time students could be coordinating meetings and group activities with 10 to 16 other individuals.

Historically, subject conveners, students, and parents have noticed difficulties with group assignments. The organisation of administrative roles within the school is such that students experiencing problems and issues in any subject within the degree(s) would generally report the problems, in the first instance, to the "Program Director." The authors had each been fulfilling the role of "Program Director" for the programmes investigated and were aware of a range of issues in group assignments across a reasonably large student cohort. Problems seemingly centre on issues such as inequality in marking and group conflict. In one programme, problems within group assignments had become moderately serious, with two specific instances requiring the intervention of the Head of School to resolve the issues. While it is not necessarily uncommon for issues within group assignments to reach a stage where outside intervention is needed to resolve tension, these two specific instances were particularly worrisome for the students and staff involved.

In addition, on a personal (pastoral) level, we were aware that the problems faced by many students in group assignments were adding to the stress felt by students. For students already struggling with the pressures of university life in general, the added burden of trying to work within a seemingly dysfunctional team was often the "last straw."

As a result, the following questions arise:

- Why use group assignments in subjects?

- Do students prefer group or individual assignments?

- Do students encounter problems more often than staff realize?

- What strategies need to be implemented to resolve and manage problems within group assignments?

Our research focussed on examining attitudes toward, and rationale for, the use of group assignments. In particular, we focused on whether group assignments were considered by staff and students to be a valid, equitable, and reliable part of an overall assessment strategy. Given the results of our study, a strategy for future group work is suggested.

\section{Method}

A questionnaire was administered at the end of two final year classes in the School of Computing and Information Technology at Griffith University. All students, 69 in total, completed the questionnaire. A similar questionnaire was given to 12 staff members. The questionnaires were anonymous.

\section{Results}

\section{Perceiving Problems}

It was found that only 2 of the 12 staff (16.7\%) reported that they had "frequently" encountered problems when they had used group assignments. Both of these staff members said they did not use group assignments anymore. Another staff member who said he had "sometimes" encountered problems also 
How Fair are Group Assignments?

said he no longer used them. All other staff members still used group assignments; of these, 3 said the y encountered problems "rarely" and 6 said they encountered them "sometimes." No staff member reported never having problems with group assignments.

The results for the students were startlingly different. There were 68 students who responded to the question concerning the extent to which they had experienced problems with group assignments. Like staff members, no student reported never having problems. However, 32 of the 68 students (47\%) said they had "frequently" encountered problems. The difference in responding "frequently" compared with responding "rarely" or "sometimes" was statistically significantly different for the students and staff, with Fisher's Exact Probability 1-tailed test, $p=.046$. It appears, then, that the staff are not aware of the extent of the problems students face. Of the remaining 36 students, 24 said they encountered problems "sometimes", and 12 said they "rarely" had problems.

\section{Making Problems Apparent to Staff}

The difference between the frequency with which students have problems and the frequency with which staff notice problems is not surprising given the students' responses to the question of how they dealt with problems. Of the 64 students who responded, only $5(7.8 \%)$ said they told the lecturer, while the other 59 kept the problem within the group or to themselves, either discussing the problem with other members, doing the work the mselves, ignoring the problems, or withdrawing material from the nonworking team me mbers. There are some clues to why the students usually keep the problems away from the lecturer. Of the 5 students who said they had approached the lecturer, 2 said that it did no good anyway, while one said it did help. One student who had not gone to the lecturer said, "It is not easy to deal with the problems as it tends to hurt [the] other [person]".

Of course, there are other ways staff could notice problems, and they did occasionally, but this was rare. One staff member had observed a problem in a class, while another had noticed the problem in a group's documentation. All other ways in which staff noticed problems came from students telling the staff member, by either just reporting the problem or through an interview or weekly consultation. In the staff comments there are clues to why students might sometimes feel that telling staff is pointless. One staff member, who no longer uses group assignments, said he ignored problems and let the exam marks differentiate between students. Two others indicated that, on discovering problems, they would act as a "facilitator" to the group's potential solving of the problem. The impression was that it was a problem for the group to solve.

\section{Preferences for Group or Individual Work}

It could be expected that for students reporting different frequencies of problems with group assignments, their preference for individual versus group assignments would differ. This seems to be the case. Of the 31 students who reported "frequent" problems and who responded to the question about preferences, 17 (54.8\%) said they preferred individual assignments, while the others said they preferred group assignments or said it did not matter. In contrast, of the 9 students who said they "rarely" had encountered problems and who responded to the question, only $2(22.2 \%)$ said they preferred individual assignments. Of the 22 students who said they had "sometimes" encountered problems and who responded to the question about preferences, $11(50 \%)$ preferred individual assignments. These differences are not significantly different. However, there is a trend for those "rarely" encountering problems to have less of a preference for individual work than the other students. 


\section{The Most Valuable Aspects of Group Work}

\section{Students}

Students were asked what they saw as the most valuable aspects of group assignments. Table 1 gives the six most valuable aspects according to students.

1. Learning from others and sharing ideas

2. Learning to work in a group, which reflects real industry

3. The social interaction

4. The division of work, which saves time

5. The fact that you can achieve more - a larger project and better quality

6. Gaining communication skills

Table 1: The six most valuable aspects of group assignments identified by students.

The rankings were similar regardless of how often students had encountered problems. However, none of the 12 students who had "rarely" encountered problems identified points 5 or 6 .

Table 2 gives the six most negative aspects according to students.

1. The inequality in the contribution of members

2. Timetable and other logistical problems

3. Conflicts

4. The fact that marking does not reflect differences in contributions

5. The fact the some members lack required skills

6. Being dependent on other people

Table 2: The six most negative aspects of group assignments identified by students.

Regardless of how often students had encountered problems, point 1 was given as the most negative aspect. For those who had "rarely" encountered problems, conflict was the second most identified problem, while for those who had "sometimes" or "frequently" encountered problems, timetabling and logistics ranked second. Point 4 was not identified by the students who had "rarely" encountered problems.

Given that the students who said they "rarely" had problems differ somewhat in their rankings and their preferences for group work from the other two groups, it is important to look at other ways the groups differ. Interestingly, there is evidence that a student's academic record may have some influence on how often they encounter problems. Of those encountering problems "rarely", 55\% normally get a passing grade, and $45 \%$ an honours grade. For the students encountering problems "sometimes", 9\% normally get a passing grade and $91 \%$ an honours grade. For those "frequently" encountering problems, 36\% normally get a passing grade and $64 \%$ an honours grade. The results for the "sometimes" groups were significantly different from the other two groups. The fact that the results for the "frequently" group are midway between those of the other two groups suggests there are probably complex factors at play. Let's focus on the "rarely" group. It may be that several students in the "rarely" group, are relatively weak and it may be these students who benefit from being in a group and who are not worried about the fact that marking does not reflect differences in contributions. There are also quite a number of weak students in the "frequently" group. While good students may frequently encounter problems in groups, some poor students also seem to often encounter problems. One of the poorer students who reported 
How Fair are Group Assignments?

"frequent" problems said that the group "constantly pressures [the] 'black sheep' until he/she does (sic) a positive contribution." The poorer students may be happy to be in a group that can help and so "rarely" encounter problems, but they may sometimes be in a group where they are pressured to give more, and in this case may "frequently" encounter problems.

\section{Staff}

Staff were also asked what they saw as the most valuable and negative aspects of group assignments. They identified points 2 and 5 of Table 1 as the most valuable aspects. The third most valuable aspect for staff was the fact that group assignments require less marking and lecture preparation. Regarding the negative aspects, the three most prominent for staff were points 1,3 , and 4 of Table 2 . No staff member identified point 2 as a problem.

\section{The Perceived Fairness of Marking}

Finally, let's consider the extent to which students felt that group marking schemes fairly dealt with individual differences in effort and ability. Of the 41 students who gave a definite response to the question, $10(24.4 \%)$ said it was fair, $23(56.1 \%)$ said it was not fair, and $8(19.5 \%)$ had mixed reactions. It is interesting that this particular question was responded to less than other questions. Some students remarked that they did not have sufficient information to answer the question, with one student, for example, stating "we don't know, we have no feedback to that extent."

\section{Discussion}

\section{A Lack of Information Flow}

It can be seen that both students and staff see that there are major problems with group assignments, though they also see there could be benefits. It can also be seen that there is a lack of information flow between staff and students. The staff are generally not aware that so many students frequently encounter problems. Also, while they identify some of the same problems as students, they do not identify the second greatest problem for students - the timetabling and logistical problems in organising a group. It seems, too, that a number of students do not feel well enough informed about the extent to which group marking schemes deal with individual effort and ability.

\section{Individual versus Group?}

It is interesting that even with the students who had encountered problems "frequently", approximately $45 \%$ still did not give a preference for individual assignments. These students obviously feel there is value in group assignments. It is thus very worthwhile to consider how the running of group assignments could be improved. To determine what new strategies could be used for group assignments, the perceived valuable and negative aspects of group assignments need to be considered more.

It is apparent from the results given in Table 1 that many students enjoy interacting with others in groups and they value the experience because they know they will probably need to work in teams as Information Technology specialists. Some of the problems they encounter may be found in varying degrees when they work in teams in industry:

- perhaps there will be an inequality in contribution, though probably not to the extreme of having someone do no work at all

- conflicts will probably arise 
- some team members may lack required skills

- they will still be somewhat dependent on other people

The other two problems identified by students may not be such big problems when working in teams in industry:

- Timetabling and other logistical problems are less likely to occur as the industry team would have more compatible timetables than the students do: often students have very different class timetables for their different subjects and often students, apart from studying, have part-time jobs.

- Marking will not be a factor in industry. There may be financial rewards or other incentives for good work and negative personal consequences for bad work. However, the work supervisor is likely to have a closer relationship to the team members than staff generally have with students. The data from the present study suggest, in fact, that the information flow between staff and students is quite low.

The results of this study suggest that a micro management strategy may be appropriate for student group assignments. There exists a need to establish a closely managed environment whereby student teams would work in a situation that more closely mimics real-world work teams: as one student remarked about group projects, "they try to be like the real world but they're really not". However, it needs to also be remembered that the third most valuable aspect of group assignments for staff was the fact that they require less marking and lecture preparation. What is needed, then, is a strategy that more closely resembles industry but that is not too burdensome for staff.

\section{A New Strategy for Group Assignments}

As discussed, students frequently see value in taking part in group assignments but are often frustrated because instead of simply facing the normal problems that can be encountered in team work in industry, they must face other problems or the same problems in an extreme form. Any new group assignment management strategy would need to address the following:

- Improving information flow between staff and students

- Ensuring reasonable equality in contribution levels

- Reducing logistical problems for both staff and students

- Providing conflict resolution procedures

- Providing an environment for learning team work skills

- Ensuring equality in marking

The new strategy was developed from two separate administrative frameworks already successfully used in subjects taught within the school. In one programme, students are required to undertake an industry internship. Internship places were advertised and students nominated for places on the basis of "best fit" according to the skills required by the client. Although every student was given a place, competition for specific "highly prized" places was keenly felt by students. Students were required to submit a "mini CV," highlighting their skills and experience and to write to short key selection criteria. The internship had been managed for three years through an online learning environment that included a weekly reporting facility for students. Industry partners were provided with access to a password protected section in order to access internship information docume nts, submit weekly attendance reports and a final report and student mark. The system worked effectively with a low level of technical maintenance required. The implementation of the online site meant that administrative requirements (associated with course management and requirements tracking) were effectively managed online. 
How Fair are Group Assignments?

While aspects of the management processes used in the internship subject were used in the development of the new strategy, it is not suggested that the new strategy can only be implemented using computing technology. As is demonstrated in tables 3 through 5 below, the new strategy is sufficiently flexible to be implemented either "on paper" or "on the screen." The choice of implementation is largely a matter of personal administrative preference of the lecturer(s) involved.

In the second subject, group assignments had been managed through a weekly reporting process and a "scalable" marking framework. Student teams were required to report to the lecturer each week to discuss progress and any other issues arising. The marking scheme for the subject was structured to allow for increases or decreases in individual student marks, depending on peer evaluations.

The new strategy incorporated these successful elements. Three important features of our micro management strategy are: first, an academic staff member acts in a role equivalent to a workplace "group manager;" second, an environment is provided for weekly meetings with the "group manager" and the group; and third, work contracts are signed.

From these three features, there are other emergent features that should alleviate the problems that need to be addressed.

The suggested micro management strategy is designed to run alongside the usual project management processes implemented by each group. It is also recommended that some initial time be spent on discussing team work processes including conflict resolution and possible problems, the amount of time depending on how much work the class has already done on such topics. There are three phases in the strategy.

1. An initiation phase where the "group manager" advertises positions on projects, students apply to the positions, and appointments are made.

2. A management phase throughout which the "group manager" and the group meet according to an agreed schedule and during which the group members agree to work according to agreed-upon contracts.

3. A completion phase where a "post mortem" and marking take place.

Managerial roles are assigned as follows:

- Management board:

which consists of academic staff members who each supervise a project group

- Group Manager

who is an academic staff member assigned to a project group

- Project Manager

who is a student group member

The aim of the initiation phase is to divide the class into effective groups that will work together well and that consist of members who are somewhat comparable in terms of effort they are likely to put in and where students are treated equally regardless of the position in the "social structure" of the class. To this end students would respond to "job advertisements." In their application they would need to say why they want the position and how they are qualified for it. They would also need to provide information on times when they cannot work on the project. To ensure fairness, they could use their student ID and be asked not to give their current Grade Point Average. The idea is that people are put into groups according to how much effort and ability went into constructing the application and on having a compatible timetable with other members. Having members who seem to be offering the same amount of effort and who do not have timetable clashes should go a long way towards overcoming problems. The 
Ford \& Morice

\begin{tabular}{|c|c|c|}
\hline DESCRIPTION & STAFF ACTIVITIES & $\begin{array}{c}\text { STUDENT } \\
\text { ACTIVITIES }\end{array}$ \\
\hline $\begin{array}{l}\text { This phase occurs at the } \\
\text { commencement of the } \\
\text { subject and comprises: } \\
\text { - subject organisational } \\
\text { activities } \\
\text { - team application and } \\
\text { selection processes } \\
\text { - team formation } \\
\text { - first team meeting }\end{array}$ & $\begin{array}{l}\text { At the completion of this phase staff will have: } \\
\text { - informed students of process and procedure } \\
\text { - created simulated 'job advertisements' for each } \\
\text { project and project position } \\
\text { - posted 'job advertisements' to inform students } \\
\text { of offerings } \\
\text { - short listed candidates for specific 'jobs' (with } \\
\text { the management board) } \\
\text { - assigned all applicants to a suitable project } \\
\text { - Informed all applicants of outcome } \\
\text { - assigned staff member 'group manager' to each } \\
\text { team } \\
\text { - ensured all team members have a copy of the } \\
\text { 'team member contact sheet' }\end{array}$ & $\begin{array}{l}\text { At the completion of } \\
\text { this phase all students } \\
\text { will have: } \\
\text { - selected and responded } \\
\text { to a maximum of two } \\
\text { 'job advertisements' } \\
\text { - submitted a CV for the } \\
\text { advertised positions } \\
\text { - been assigned to one } \\
\text { project team on the basis } \\
\text { of CV and timetable } \\
\text { - contacted all team } \\
\text { members listed on the } \\
\text { 'team member contact } \\
\text { sheet' }\end{array}$ \\
\hline
\end{tabular}

strategy would also help students develop resume writing skills. Table 3 sets out some of the processes involved in the initiation phase.

While the work involved in the initiation phase might seem onerous, much of it needs to be done regardless of how a subject is run. The "job advertisements", for example, would include information normally given on an assignment sheet. Some marks could be awarded on the basis of the CVs.

The major aim of the management phase is to create a good information flow between staff and group members. It should ensure that the staff member is very well informed of who is doing what. It should also give the students clear guidelines of what is expected of them as valuable group members. To this end, students would be expected to agree on and sign work contracts and set out a schedule of meetings and to keep time sheets. It should also provide a forum for students to admit the existence of conflicts

\begin{tabular}{|c|c|c|}
\hline DESCRIPTION & STAFF ACTIVITIES & $\begin{array}{c}\text { STUDENT } \\
\text { ACTIVITIES }\end{array}$ \\
\hline $\begin{array}{l}\text { This phase commences at } \\
\text { the completion of the initia- } \\
\text { tion phase and continues } \\
\text { until all project deliverables } \\
\text { are completed. This phase } \\
\text { comprises: } \\
\text { - individual work contracts } \\
\text { - group work schedules } \\
\text { - individual weekly time- } \\
\text { sheets }\end{array}$ & $\begin{array}{l}\text { During this phase the group manager will: } \\
\text { - negotiate, approve and implement individual } \\
\text { work contracts with each group member } \\
\text { - approve all proposed group meeting and } \\
\text { work schedules } \\
\text { - attend each weekly group meeting with the } \\
\text { group manager } \\
\text { - collect and sign off all individual weekly } \\
\text { timesheets } \\
\text { - maintain a written weekly attendance, par- } \\
\text { ticipation and contribution register } \\
\text { - dismiss members not complying with their } \\
\text { contract }\end{array}$ & $\begin{array}{l}\text { During this phase stu- } \\
\text { dents will: } \\
\text { - negotiate and imple- } \\
\text { ment individual work } \\
\text { contracts } \\
\text { - in collaboration with } \\
\text { group members develop } \\
\text { group meeting and work } \\
\text { schedules } \\
\text { - attend each scheduled } \\
\text { meeting } \\
\text { - complete and submit a } \\
\text { weekly timesheet }\end{array}$ \\
\hline
\end{tabular}


How Fair are Group Assignments?

and attempt to reach a resolution. Where a student does not keep to a contract the Group Manager should "dismiss" the student, replicating what would happen in industry - in this context the student could be required to do a project by his or herself and be penalised $10 \%$. This would help alleviate the problem that some students noted - that unlike in real industry the noncontributors cannot be "sacked". Table 4 sets out some of the processes involved in the management phase.

The management phase need not be burdensome on staff. The weekly meetings with the Group Manager, the "group manager," could be held during scheduled class time. For example, the last half hour of a class could be devoted to group meetings where the "group manager" goes from group to group, discussing problems, collecting sheets and attendance records.

The aim of the completion phase is to give feedback to students on their performance and to give students time to analyse what they have learnt about working in a team. Given that the staff member has been in good contact with the group members throughout, marks should be able to be awarded fairly on the basis of participation, contribution, and contract expectations. There would be an individual mark for each individual, not a group mark. Table 5 sets out some of the processes involved in the completion phase.

\begin{tabular}{|c|c|c|}
\hline DESCRIPTION & STAFF ACTIVITIES & $\begin{array}{c}\text { STUDENT } \\
\text { ACTIVITIES }\end{array}$ \\
\hline $\begin{array}{l}\text { This phase commences at } \\
\text { the completion of the Man- } \\
\text { agement phase. This phase } \\
\text { comprises: } \\
\text { - marking } \\
\text { - project post mortem }\end{array}$ & $\begin{array}{l}\text { During this phase the group manager will: } \\
\text { - assign each group member a mark for 'con- } \\
\text { tract', 'participation' and 'contribution' } \\
\text { - give each group member feedback on overall } \\
\text { performance }\end{array}$ & $\begin{array}{l}\text { During this phase stu- } \\
\text { dents will: } \\
\text { - attend a project post } \\
\text { mortem } \\
\text { - attend a feedback ses- } \\
\text { sion with the group } \\
\text { manager }\end{array}$ \\
\hline
\end{tabular}

The completion phase should be no more burdensome on staff than any other grading. In fact, it should be easier given the knowledge the staff member has gained of the group members throughout the running of the subject.

It is worth noting that the use of a micro management strategy could be perceived by both staff and students as unnecessarily prescriptive and intrusive. However, the results of our study suggest that in order to solve the main problems arising from group assignments, and to adequately replicate industry within the (typically) less structured university environment, groups need to be closely monitored by staff.

It will be the case that not all projects are of suitable size and scope to gain benefit from using the suggested management strategy. For example, where the class enrolment is small (perhaps under 15) and where students are asked to work in very small groups comprising only pairs, the use of the suggested micro management strategy will be unnecessarily prescriptive and will add an unnecessary administrative burden.

\section{Conclusion}

It is all too apparent that many students, often very good students, suffer needlessly when doing group assignments. While some academics might claim that it is good to let students face problems arising from group work, it is pointless having them face problems that they will not see in the workplace. Simply making students do assignments together is not preparing them for team work in industry. It is not 
simulating "real life in industry". It stresses many students and gives them grades they do not deserve either inflated or deflated.

It appears that staff use group assignments for a number of reasons. Some staff hold the belief that group assignments replicate or at least partially recreate the scope and working environment commonly found in employment situations. Sometimes group assignments are used as a way of coping with large class sizes, while in other cases group assignments are used because they form part of the assessment strategy that has been inherited by a new staff member. By taking an approach that really does seek to replicate some of the management techniques of industry it may be possible to overcome many of the problems identified as occurring in group assignments. Specifically:

- information flow between staff and students is increased

- students who are likely to put in equal contributions can be grouped together

- timetabling and other logistical problems will be lessened

- conflicts should more easily be admitted and resolved

- the environment is likely to help students learn team skills

- the marking will reflect the contribution and ability of individual members

We realise that it is unrealistic to assume that all students will come into groups with highly developed interpersonal and team work skills. These skills are developed over time within a supported environment. It is important to ensure that when we use group assignments in subjects we are also providing a supported environment to students - one where they are given time to develop the skills, both technical and team skills that they will need to function as effective team members in the workplace. All students need to feel confident that their efforts will be recognised and fairly rewarded and that when they arise, serious issues will be identified and resolved. Our suggested management strategy provides the framework for a supported learning environment - one in which students can be confident that the many benefits of working on a group assignment can be enjoyed.

Finally, we realize that the suggested strategy will not solve all problems. However, we believe that by constantly striving to address the problems encountered with group assignments by using management techniques that seriously attempt to replicate those in industry, progress can be made. The more we can replicate such processes the more the students will be satisfied and the more they will really learn skills that will help when they encounter team work in industry.

\section{References}

Baskin, C. (2001). The Titanic, Volkswagens and collaborative group work: Remaking old favourites with new learning technologies. Australian Journal of Educational Technology, 17, 265-278.

Brokaw, A. J. \& Rudd, D. V. (2002). Strategies for team selection for group projects in marketing. In Great Ideas for Teaching Marketing. Retrieved October 17, 2002 from http://www.swlearning.com/marketing/gitm/gitm4e08-07.html

Candy, P. C., Crebert, G. \& O’Leary, J. (1994). Developing lifelong learners through undergraduate education. Canberra: Australian Government Publishing Service.

Chang, V. (1999). How can conflict within a group be managed? In Martin, K., Stanley, N. and Davison, N. (Eds), Teaching in the Disciplines/Learning in Context, 59-66. Proceedings of the 8th Annual Teaching Learning Forum, The University of Western Australia, February 1999. Perth: UWA. Retrieved Nove mber 27, 2002 from the World Wide Web http://cea.curtin.edu.au/tlf/tlf1999/chang.html

Cohen, E. (1994). Collaborative learning: higher education, interdependence, and the authority of knowledge. Baltimore: John Hopkins University Press. 
Fall, R., Webb, N. \& Chudowski, N. (2000). Group discussion and large-scale language arts assessment: Effects on students' comprehension. American Educational Research Journal, 37, 911-9451.

Johnson, D. \& Johnson, R. (1996). Conflict resolution and peer mediation programs in elementary and secondary schools: A review of the research. Review of Educational Research, 66, 459-506.

Michalchik, V., Schaeffer, E., Tovar, L., Steinbeck, R., Bhargava, T., Kerns, C., Engel, C., \& Levtov, R. (2001). Small group collaboration in the large lecture setting: Collaborative process, pedagogical paradigms, and institutional constraints. Paper presented at the annual meeting of the American Educational Research Association, Seattle, WA.

Morris, R. \& Hayes, C. (1997). Small group work: Are group assignments a legitimate form of assessment? In Pospisal, R. \& Willcoxson, L. (Eds), Learning Through Teaching, 229-233. Proceedings of the 6th Annual Teaching Learning Forum, Murdoch University, February 1997. Perth: Murdoch University. Retrieved October 17, 2002 from the World Wide Web http://cea.curtin.edu.au/tlf/tlf1997/morris.html

Parsons, D.E. \& Drew, S.K. (1996). Designing group project work to enhance learning: Key elements. Teaching in Higher Education, 1 (1), 65-80.

Thong, M. (1995). Facilitating the learning of group processes in management courses via a group-based, 'parcel-marking' student assessment approach: Experiences to date. In Summers, L. (Ed), A Focus on Learning, 257-261. Proceedings of the 4th Annual Teaching Learning Forum, Edith Cowan University, February 1995. Perth: Edith Cowan University. Retrieved October 17, 2002 from the World Wide Web http://cea.curtin.edu.au/tlf/tlf1995/thong.html

\section{Biographies}
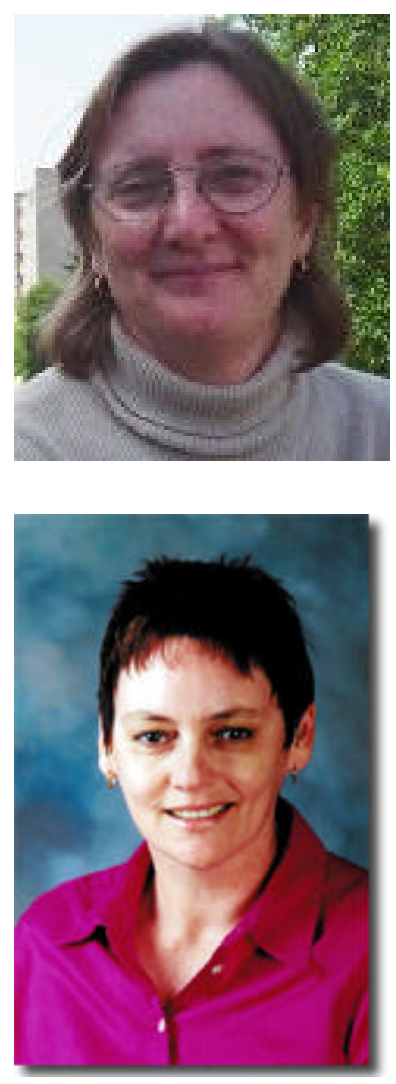

Dr. Marilyn Ford is a senior lecturer in the Computing and Information Technology School at Griffith University. She has extensive research and publications in the areas of reasoning, sentence perception and production, and user interface design.

Jenny Morice is a senior lecturer in the Department of Creative Technologies at the University of Portsmouth. She is interested in flexible learning in higher education and in the efficacy of adventure style computer games in education. 